\title{
A new test for canine intestinal mucosa permeability
}

\author{
Ragnvi Hagman ${ }^{1 *}$, Pernilla Rosberg ${ }^{1}$, Anas Al-Saffar ${ }^{2}$, Dominic Luc-Webb² \\ From Animal Obesity - causes, consequences and comparative aspects \\ Uppsala, Sweden. 14-16 June 2015
}

\section{Introduction}

Increases in mucosal intestinal permeability may cause pathological leakage of bacterial products, inducing inflammation. Low-grade systemic inflammation has been reported in overweight humans. Probes used for permeability evaluation in humans have not yet been evaluated in dogs.

\section{Objective}

To determine suitability of human permeability probes (riboflavin, lactulose, mannitol and sucralose) for canine obesity models.

\section{Methods}

Fourteen healthy dogs were examined as baseline group. They were given all four probes per os using human doses corrected for weight and reported to be harmless for dogs. Urine samples were collected 2, 4 and $6 \mathrm{~h}$ after ingesting probes. Urinary excretion was quantified.

\section{Results}

The least squares means of mannitol proportion (excreted/ingested \pm SE) was $15.6 \%( \pm 2.0), 11.0 \%( \pm$ $2.1)$ and $5.5 \%( \pm 2.1)$ for urine sampled 2,4 and $6 \mathrm{~h}$ after ingestion $(\mathrm{p}<0.0001)$. Hence, the majority of mannitol absorption and secretion representing upper gastrointestinal leakage was completed by $4 \mathrm{~h}$. Riboflavin followed a similar temporal profile, defining $4 \mathrm{~h}$ as a cutoff for upper vs lower gut permeability. Probes were well tolerated.

\section{Conclusions}

Data obtained in the study indicates that probes used for humans can be used for intestinal permeability evaluation in dogs.

\section{Authors' details}

'Department of Clinical Sciences, Swedish University of Agricultural Sciences, Uppsala, Sweden. ${ }^{2}$ Department of Medical Sciences, Gastroenterology and Hepatology Unit, Uppsala University, Uppsala, Sweden.

Published: 25 September 2015

doi:10.1186/1751-0147-57-S1-016

Cite this article as: Hagman et al:: A new test for canine intestinal mucosa permeability. Acta Veterinaria Scandinavica 2015 57(Suppl 1):016.

Submit your next manuscript to BioMed Central and take full advantage of:

- Convenient online submission

- Thorough peer review

- No space constraints or color figure charges

- Immediate publication on acceptance

- Inclusion in PubMed, CAS, Scopus and Google Scholar

- Research which is freely available for redistribution

Submit your manuscript at www.biomedcentral.com/submit
() Biomed Central

'Department of Clinical Sciences, Swedish University of Agricultural Sciences, Uppsala, Sweden

Full list of author information is available at the end of the article 